\title{
Szklane domy
}

\author{
Katarzyna Szmuryło \\ Politechnika Lubelska, Wydziat Budownictwa i Architektury, \\ Katedra Architektury, Urbanistyki i Planowania Przestrzennego, \\ Nadbystrzycka 40, 20-618 Lublin, e-mail: katarzynaszmurylo@gmail.com
}

Streszczenie: O tym jak wyglądają dzisiejsze „szklane domy”. Czy są zaniedbaną pozostałością minionych lat? Czy owa idea przetrwała do dziś, a może zapoczątkowała coś nowego lub ewoluowała? Czy potrzebna jest aż w takim stopniu transparentność architektury mieszkaniowej? O możliwościach jakie daje nam szkło które jest materiałem o niemal nieograniczonych zastosowaniach, ciągle doskonalonym dla potrzeb rozwijających się tendencji architektury, a przede wszystkim potrzeb człowieka. Grimshaw przewiduje, że „w przyszłości nie będziemy projektować budynków, ale organizmy zdolne do zmian i adaptacji w stopniu zgodnym z technologią chwili, w której się znajdujemy". Domy muszą być funkcjonalne, inteligentne i piękne. To miejsce gdzie możemy odpocząć, być w poczuciu intymności i bezpieczeństwa. Próby odnowienia naszych związków z przyrodą pojawiają się bez względu na to gdzie i jak mieszkamy. Człowiek chce cieszyć się widokiem, czuć podmuch wiatru i mieć dużo słońca.

Słowa kluczowe: architektura mieszkaniowa, idea szklanych domów, konstrukcje szkieletowe, ściana osłonowa

\section{Złożoność architektury mieszkaniowej}

Budownictwo mieszkaniowe to najbliżej znana dla przeciętnego człowieka część architektury. Jest to niebagatelnie ważna kategoria, gdyż człowiek obcuje z nią lub też zmaga się z nią na co dzień. Przy zestawieniu relacji między tworzącymi ją teoriami społecznymi, estetycznymi i teoriami projektowania można zauważyć, że architektura mieszkaniowa jest szczególnie wymagającą i złożoną dziedziną.

\section{Szklane tafle symbolem nowoczesności lat trzydziestych}

Jeśli mówimy o domach to aż chcemy mówić o takich w których chcielibyśmy mieszkać. Mit o szklanych domach oferuje nam ekskluzywność i dostępność o jakiej marzymy. Został on przywołany w literaturze pięknej przez Stefana Żeromskiego w „Przedwiośniu”, przedstawiając je jako poprawę higienicznych warunków życia najuboższych. W książce szklane domy pojawiają się podczas jednej z rozmów w których ojciec chciał przekonać syna, że Polska to kraj powszechnej szczęśliwości. W szklanych domach mają mieszkać zwyczajni ludzie, a na wybrzeżu w olbrzymiej hucie szkła, miały być wytapiane elementy domów - szklane tafle.

- Jakaś - mam wrażenie - krucha i łatwo tłukąca się cywilizacja.

- Szkło się tatwo tłucze. 
- Nie takie szkło! Baryka - nasz imiennik - produkuje szkło belkowe. Za pomoca olbrzymiej sity, którq ma darmo od prąu zachodniego, zwłaszcza wobec wiatrów zachodnich, które tam trwaja niemal stale, otrzymuje niezmiernq mase popędu elektrycznego, z które- go pomoca topi piasek nadmorski...

- To, oczywiście, jego sekret?

- Sekret. Z olbrzymiej masy ptynnej wyciaga gotowe belki, tafle, kliny, zworniki, odlane, a raczej ulane wedtug danego architektonicznego planu. Cały szklany parterowy dom, ze ścianami ściśle dopasowanymi z belek, które się składa na wieniec, a spaja w ciagu godziny, Z podtoga, sufitem i dachem z tafel-oddaje nabywcy gotowe. W domach tego typu, wiejskich, czyli jak się dawniej mówiło, chłopskich, nie ma pieców. Goraca woda $w$ zimie idzie dokoła ścian, wewnatrz belek, obiegając każdy pokój. Pod sufitem pracuja szklane wentylatory normujace pożadane ciepło $i$ wprowadzajace do wnętrza zawsze świeże powietrze...

- Mylisz się, niewierny! Tymi samymi wewnętrznymi rurami idzie $w$ lecie woda zimna obiegająca każdy pokój. Woda ochładza ściany, wskutek czego jest w takim domku podczas największego upału jak w bakińskiej naszej piwnicy, tylko bez jej zgnilizny $i$ odoru. Táż woda zmywa się stale szklane podłogi, ściany i sufity, szerzac chłód i czystość. Nawet nie wymaga ci to żadnej pracy specjalnej, gdyż rury od-prowadzajace zużyta wodę i wszelka nieczystość uchodzq do szklanych kloak, wkopanych opodal $w$ ziemie.

- Jakieś gablotki, do licha, nie ludzkie mieszkania!

- Istne gablotki. Chłop polski, niezbyt, powiedzmy, przepadajacy za czystościa, jak to jest wszędzie na wsi, przy pracy koło krów, koni, kóz i owiec - choćby nie chciat, musi sobie $w$ izbie zaprowadzić, zapuścić - uważasz - czystość, ̇̇eby mu snadź w izbie szklanej nie było goraco. Wcią̇ mu baba zmywa izbę, ściany, podłoge - a wilgoci ani krzty, bo nie ma co gnić ani pleśnieć, ani śmierdzieć widzialnym czy niewidzialnym brudem, jako że naczynia wszystkie, sprzęty, graty, meble - szklane.

\section{- Oszaleć!}

- Oszaleć, ale z zachwytu. Bo te domy komponuja artyści. Wielcy artyści. Dzisiaj sq ich tam już setki. I powiem ci, nie sa to nudziarze, snoby, żebraki, produkujace bzdury i gtupstwa, śmieszne cudactwa i matpiarstwa dla znudzonych sobq i nimi bogaczów, lecz ludzie madrzy, pożyteczni, twórcy świadomi i natchnieni, wypracowujacy przedmioty ozdobne, piękne a użyteczne, liczne, wielorakie, genialne a godne jak najszerszego rozmnożenia - dla pracowników, braci swych, dla ludu. Domy sa kolorowe, zależnie od natury okolicy, od natchnienia artysty, ale i od upodobania mieszkańców. Sa na tle okolic leśnych domy śnieżnie białe, $w$ równinach - różowe, $w$ pagórkach - jasnozielone, $z$ odcieniem fioletu albo koloru nasturcji. Domy te sq najwymyślniej, najfantastyczniej, najbogaciej zdobione, wedtug wskazań artystów i upodobań nabywców, bo belkę ściany i taflę dachu można $w$ stanie jej płynnym zabarwić, jak się żywnie podoba. Co tylko bezgraniczna fantazja kolorysty może poczać i ujrzeć $w$ boskiej tajemnicy organu oka, $w$ darze niebios, we wzroku - jaka tylko barwa jawi się $w$ przepychu kwiatów na tace pod koniec czerwca, to wszystko, to wszystko ujęte w natchnieniu, sformułowane przez twórczq świadomość, artystycznq mądrość i akty pracowitej woli, zobaczysz $w$ zewnętrznych $i$ wewnętrznych kompozycjach kolorowych chat nowoczesnych polskich chłopów. Sa to istne marzenia futurystyczne, ucieleśnione $w$ podatnym i posłusznym szklanym materiale [7]. 
Taki opis wydaje się obiecujący i tak też było w latach trzydziestych - szklane domy opanowały świadomość całego pokolenia. Idea szklanych domów okazała się symbolem fantastycznej wizji przyszłości. Dzięki stosowaniu na szeroką skalę stają się wzorcem estetycznym, symbolem nowoczesności. Owe pokolenie było zafascynowane nieograniczonymi możliwościami nauki i umysłu ludzkiego, gdyż odkrycia naukowe pozwalały wierzyć, że świat pójdzie drogą postępu technicznego, przybrały one postać lawinową: 1900 - teoria kwantów, 1903 - pierwszy lot samolotem, 1905 - teoria względności Einsteina, 1909 - pierwszego radioodbiornik i nadajnik. Wszystko to pozwalało uwierzyć, że i domy ze szkła mogą stać się realne [1].

\section{Historia popularności domów lekkich i błyszczących [3]}

Przyjrzyjmy się bliżej historii popularności szklanych tafli. Jest to jeden z podstawowych składników domów tak wspaniale lekkich i błyszczących. Proces wdrażania szkła przebiegał w sposób naturalny. Trudno jest wybrać określoną datę czy wydarzenie, podobnie jak trudno jest ogłosić dokładny początek jakiejś nowej epoki. Idea obecna była już w średniowieczu i realizowana w sposób plastyczny w architekturze gotyckiej, pierwotnie służyła chrześcijańskiej symbolice religijnej Domów Bożych, gdyż uważano że własne domy nie są tak istotne żeby się nimi zajmować, a przynajmniej nie tak jak robimy to dziś.

Suger, opat St. Denis przytacza interpretację wielkich powierzchni okien witraży prześwietlających słynny chór, gdzie piękno wraz ze światłem słonecznym służyć ma symbolice wielu spraw.

Suger uważat, że Bóg jest świattem. W tej świattości początkowej[....], uczestniczy wszelkie stworzenie. Wszelkie stworzenie otrzymuje i przekazuje światło boskie wedtug swej możności, to znaczy zależnie od szczebla, jaki zajmuje $w$ drabinie istot, zależnie od poziomu na jakim umieścita je hierarchii myśl Boża. Wywiedziony ze światła wszechświat sam wysyła potoki jasności, a światto emanujace $z$ istoty pierwszej wyznacza nieodmienne miejsce wszystkiemu co stworzone. Ale też $i$ wszystko zespala. Jako więź miłości przenika świat, jest jego ładem i spójniq (...) Wszystko wraca do Niej [Istoty Najwyższej] przez rzeczy widzialne, które im wyżej $w$ hierarchii umieszczone, tym lepiej odbijaja Jej światto. I tak, to co stworzone, po szczeblach analogii i współzgodności wiedzie ku temu co najwyższe. (...) Sam jako Światło Absolutne Bóg jest $w$ każdym stworzeniu mniej lub bardziej przesłonięty $w$ zależności $w$ jakim stopniu stawia ono opór Jego promieniowaniu; wszystko jednak, co stworzone, jest w jakiejś mierze odbiciem Bożym, przed każdym bowiem kto spoglada $z$ mitościa, odsłania te czastkę światła, jaka' w sobie zawiera. Ta koncepcja jest kluczem do nowej sztuki, do sztuki Francji, której wzniesiony przez Sugera kościół opacki jest wzorem. Jest to sztuka blasków i pielgrzymowania światła. Celem stylu gotyckiego było maksymalne oświetlenie kościoła. Temu stużyły olbrzymie okna i uzależniona od tego reszta. W kościele romańskim światto jest czymś ostro odcinajacym się od ciężkiej, mrocznej, napierajacej zewszą masy ścian. Ściana gotycka natomiast jest jakby przepuszczalna: światło wsącza się w nia i przenika przez nią, zespala się z niq i przeobraża ja [8]. 


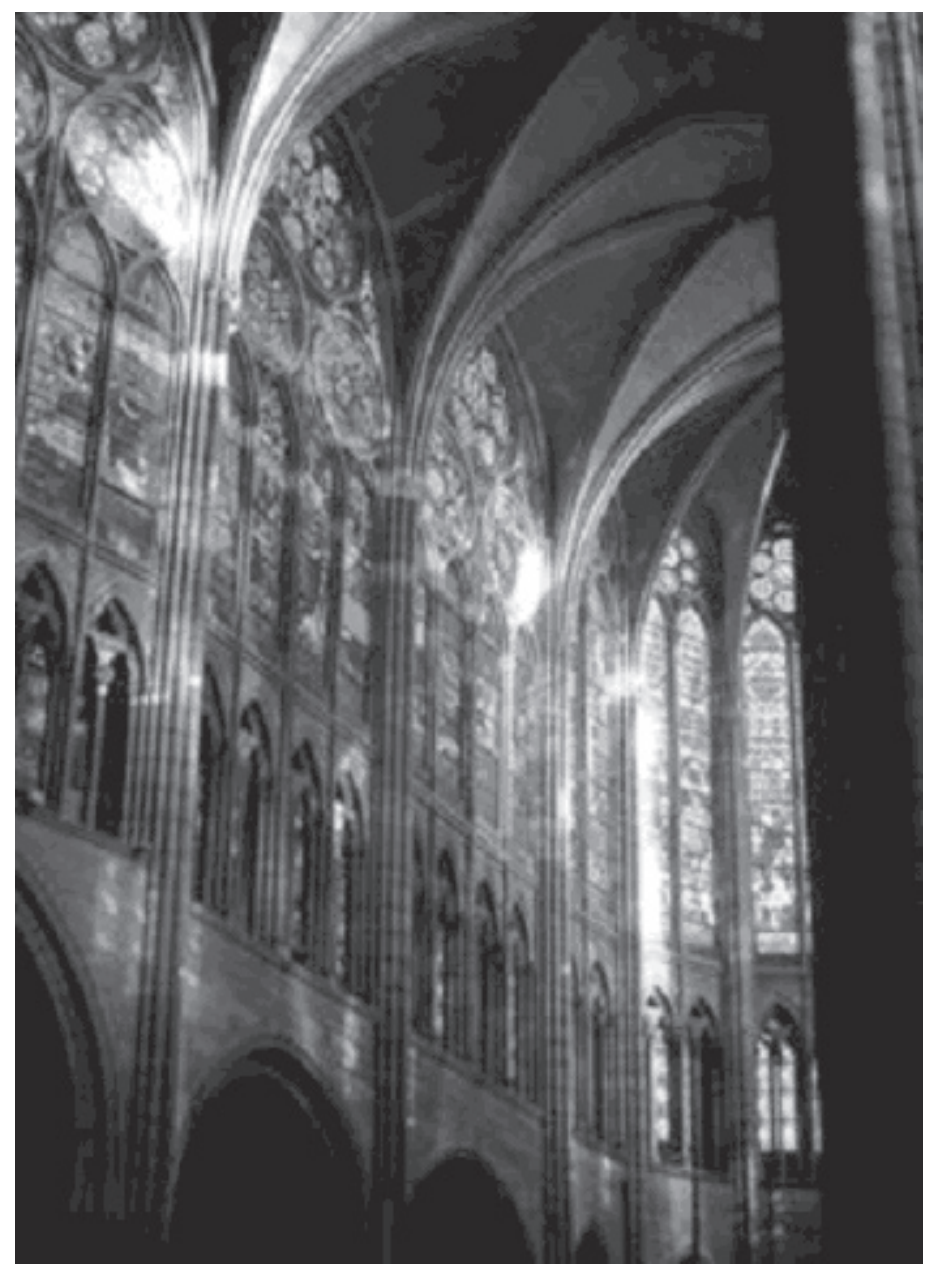

Rys. 1. Opactwo St. Denis w Saint-Denis, 1136 - schyłek XIII Francja. Zdjęcie/photo: Ben Johnson, www.wikipedia.pl.

Fig. 1. Basilica of St. Denis in Saint-Denis, 1136 - XII, France.

Transparentność architektury zaczęła służyć również celom doczesnym, zaczynając od protomodernistycznych obiektów przemysłowych na przełomie XVIII i XIX wieku. Były to cele skrajnie utylitarne - doświetlenie miejsc pracy w halach przędzalni bawełny - od czego wzięła się początkowa nazwa dla okna poziomego. Nadano mu nazwę „okna tkackiego”.

Zastosowanie powyższej tendencji jako dobre rozwiązanie techniczne dla architektury przemysłowej przygotowywano od stulecia, natomiast wdrożenie go do przestrzeni mieszkania wywołało kontrowersje. Rozpowszechnienie szkła w owej przestrzeni związane było z rewolucją w poglądach estetycznych. Najpełniej wyrażała się $\mathrm{w}$ pracach grupy de Stijl. Chodzi o modernistyczne przejawy przezroczystości w architekturze i związanych z nimi zastosowań. Dzięki konstrukcji szkieletowej i postępowi w dziedzinie technologii szkła, aż do prób likwidacji strefy wewnętrznej i zewnętrznej danego obiektu. To wszystko umożliwiał cienki słup ze stali połączony z dużą taflą szkła. Ludzie zaczęli fascynować się nową wizją świata 
z budynkami wydającymi się być lekkimi jak powietrze (na konstrukcji ze stali) jednocześnie chroniących przed zimnem i deszczem (z dużymi taflami szyb). Taka konstrukcja odegrała bardzo ważną rolę, gdyż to nie tylko szkło odgrywa zasadniczą rolę. Tafle są jakby pięknym opakowaniem całej konstrukcji którą mamy w środku [6].

Szklany dom, przywołany w literaturze pięknej, realizowany był pierwotnie w najbardziej elitarnych nurtach architektury wczesnego modernizmu: od projektów braci Keck w USA z lat 30-tych, przez projekty Miesa van der Rohe - willi Koller-Muller 1912, willi Farnsworth 1945-50 i Philipa Johnsona - Glass House 1949, które są archetypami.
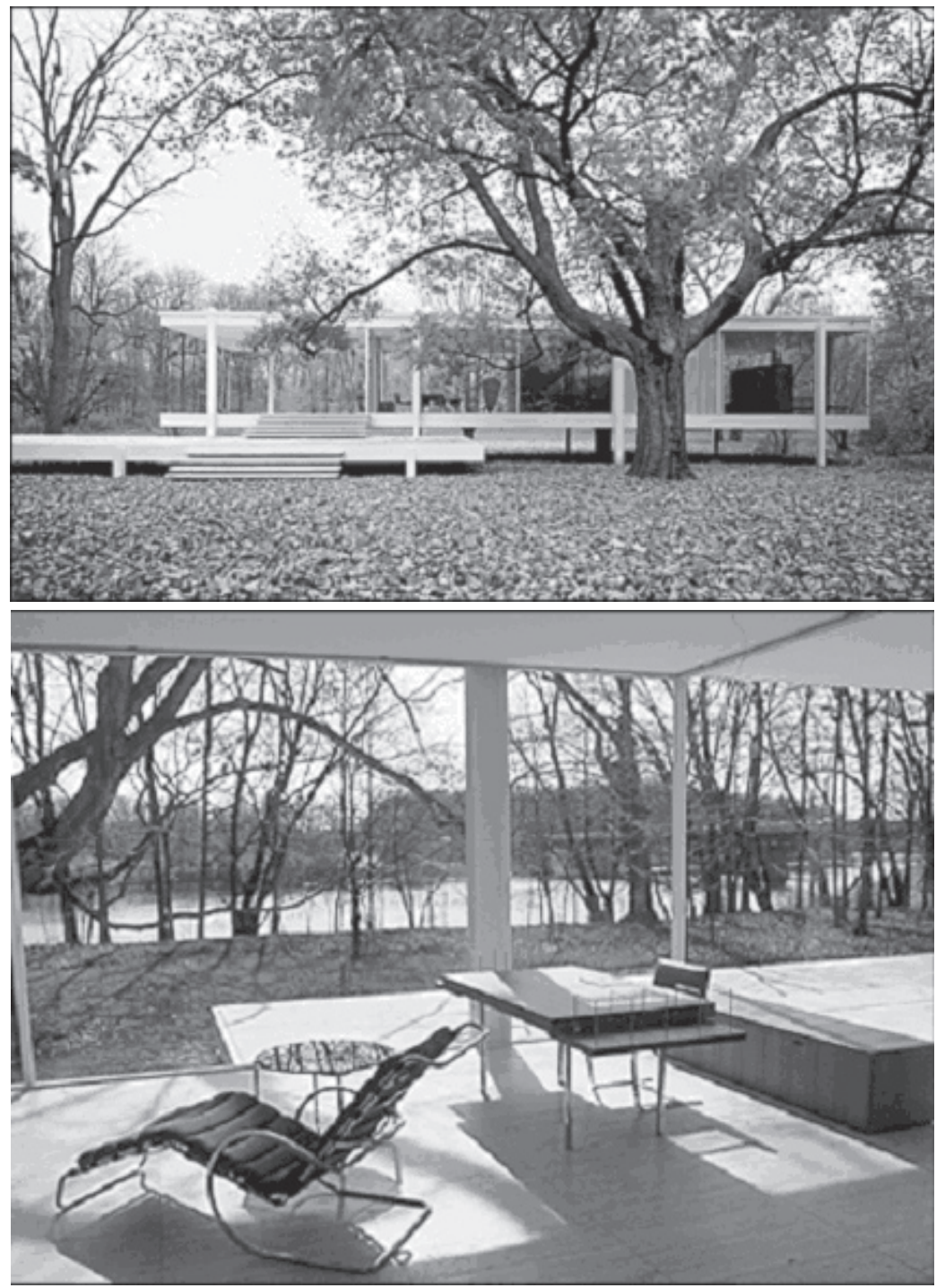

Rys. 2. Willa Farnsworth w Piano 1950, Illinois. Zdjęcie/photo: Jon Miller, Hedrich Blessing, LPCI, www.farnsworthhouse.org.

Fig. 2. Villa Farnsworth in Piano 1950, Illinois. 

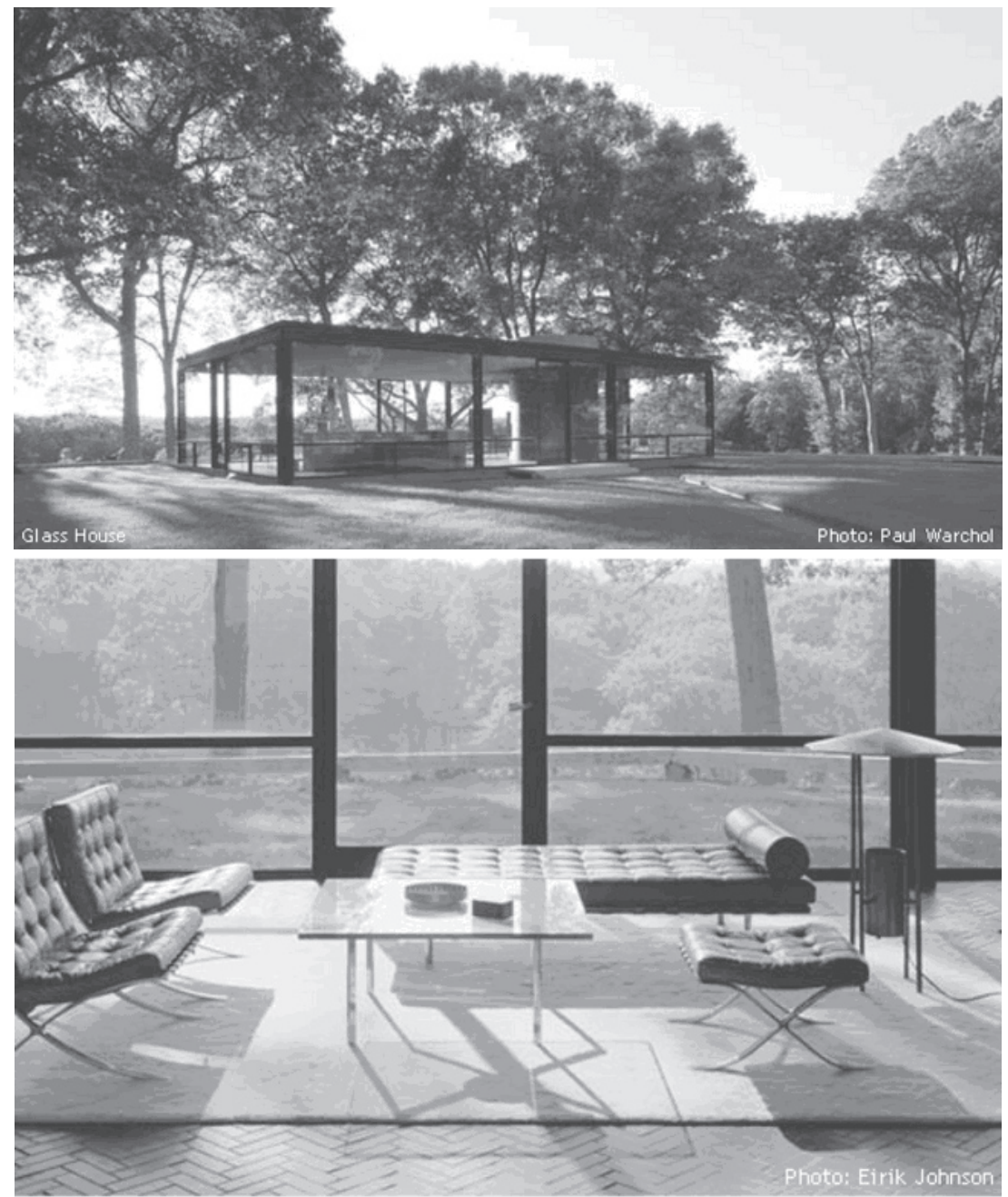

Rys. 3. Glass House w New Canaan 1949, Stany Zjednoczone. http://philipjohnsonglasshouse.org/

Fig. 3. Glass House in New Canaan 1949, United States.

Innym przykładem jest gmach szkoły Bauhausu w Dessau. Gdzie po raz pierwszy zasady sztuki współczesnej zostały przeniesione w dziedzinę nauczania. Obiekt ma szkielet żelbetowy. Niemieckie przepisy budowlane wymagały, aby słupy nośne były dużo masywniejsze od stosowanych w innych krajach. Ciagła osłona szklana zestawiona jest kontrastowo z poziomymi pasami białej ściany osłonowej u góry i u dołu budynku. Osłona szklana Gropiusa nie jest ograniczona i wykrojona przezroczysta powierzchniq, która zastosowat już chociażby Eiffel na wystawie w 1878 roku. Opływa ona gładko dookoła budynku, przy czym narożniki nie maja podparć pionowych, ani innych elementów wiażacych. Stupy ustawione sa poza szkłem, czyniac z tej osłony przykład czysto wspornikowej konstrukcji. Osłona szklana jest po prostu zawinięta wokót narożników budynku. Ściany szklane przenikaja się nawzajem dokładnie w tych punktach, w których oko ludzkie spodziewałoby się odnaleźć wyraźne podparcie catego budynku. 
W tym obiekcie spetniono dwa ważne dążenia nowoczesnej architektury. Zawieszone $w$ powietrzu zgrupowanie pionowych płaszczyzn zaspokaja nasza potrzebe zrelacjonowanej przestrzeni. Ogromna zaś przezroczystość pozwala widzieć elewację zewnętrzna $i$ wnętrze budynku: en face $i$ en profile. Uzyskano tu rozmaitość punktów odniesienia jak i równoczesność, czyli zrealizowano koncepcję czaso-przestrzeni. Mimo, że program budowy byt wymagajacy, gdyż musiat stosować się do wielu wymogów: połączenie pracowni z mieszkaniami, a także zaprojektowanie takich pomieszczeńn jak jadalnia czy świetlica [9].
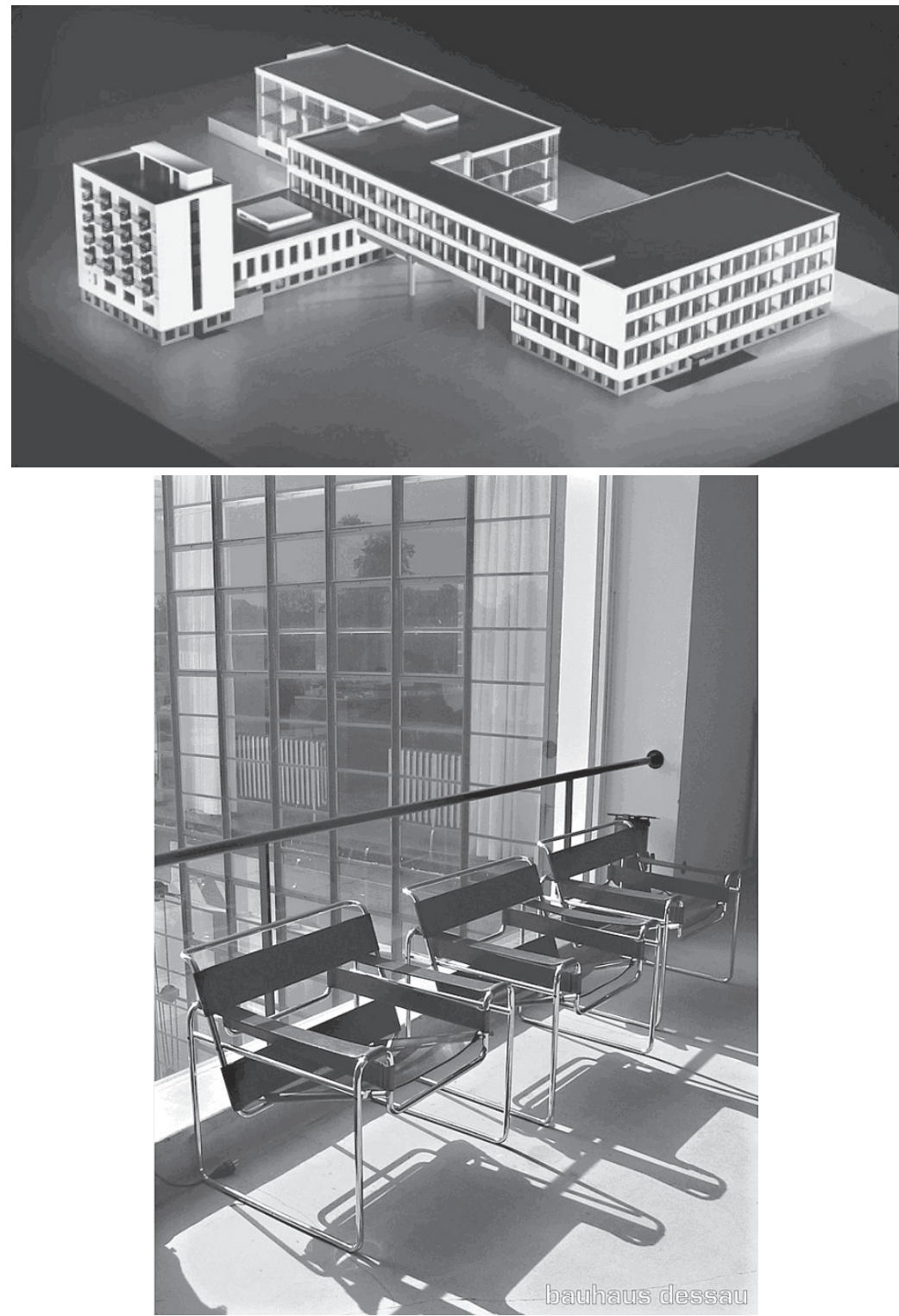

Rys. 4. Bauhaus w Dessau, 1926 Niemcy. Zdjęcie/Photo: iikari1. http://dod-projects.blogspot.com/

Fig. 4. Bauhaus in Dessau, 1926 Germany. 


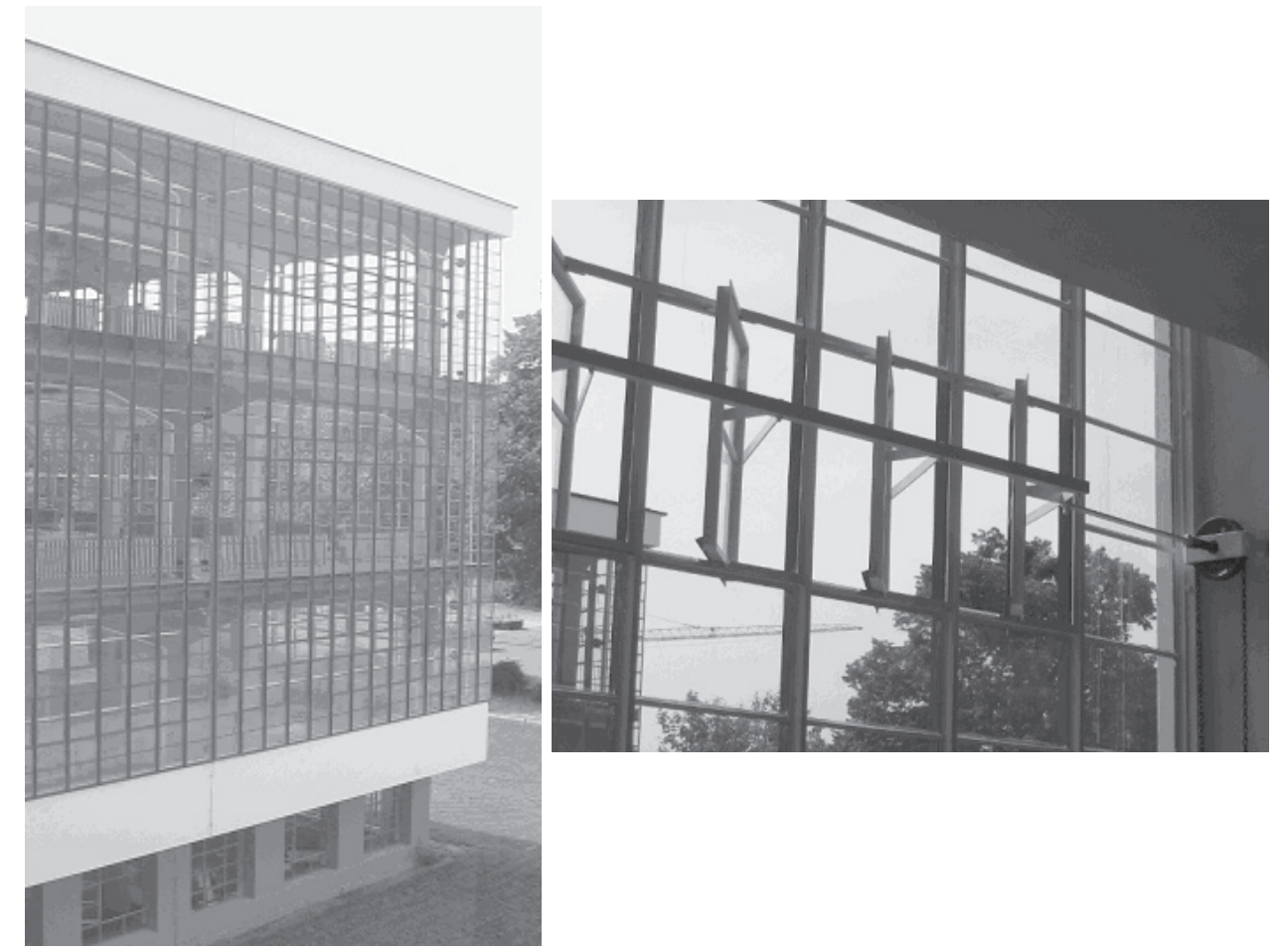

Rys. 5. Bauhaus w Dessau, 1926 Niemcy. www.wikipedia.pl.

Fig. 5. Bauhaus in Dessau, 1926 Germany.

Ściana ze szklaną osłoną zyskała sławę, także istotne znaczenie osiąga gmach Bauhausu jako całość. Gdy ukończono budowę wykazał, jak można zastosować nową koncepcję przestrzeni w układzie dużego kompleksu budynków, a było to pierwsze tego typu osiągnięcie.

Mówiąc o szkielecie żelbetowym należy wspomnieć o malarzu i architekcie jakim był Le Corbusier. Charakter jego budynków jest kojarzony z tendencjami współczesnego malarstwa. Płynna przejrzystość osiągana w pracach, tłumaczona przez Corbusiera jest wyborem najmniej interesujących przedmiotów - typu kieliszki czy butelki - aby nie odwracały uwagi od samego malarstwa. Tak naprawdę jest to wynikiem zamiłowania do lekkich, przezroczystych przedmiotów, których masa i kontury przenikają się wzajemnie. Zamiłowanie to ma tez swoje odzwierciedlenie $\mathrm{w}$ architekturze artysty. Le Corbusier rozwinął w architekturze na tej samej zasadzie przenikanie przestrzeni zewnętrznej i wewnętrznej oraz przyjmuje żelbet jako środek wyrazu swych idei w architekturze.

Początkiem kariery architekta jest rysunek z 1915 roku, który przedstawia tylko sześć żelbetowych słupów i trzy poziome płyty połączone tylko schodami. Jego zmysł artysty pozwalał mu wydobyć ukryte związki istniejące między konstrukcją żelbetową, a potrzebami człowieka. Gdyż chciał wznosić domy odznaczające się niesamowitą lekkością i stanowiły dalsze rozwinięcie „otwartego układu” stworzonego przez Franka Lloyda Wrighta. W tym celu wykorzystał te cechy ramy nośnej z żelbetu, które umożliwiają zupełnie dowolne rozmieszczenie ścian wewnętrznych. W ten sposób tworzy nową interpretację szkieletu żelbetowego. 
Problem domu mieszkalnego stanowi centrum działalności Le Corbusiera. Ustalił on pięć zasad łączących współczesną architekturę ze współczesną konstrukcją:

1. wolny słup nośny, przez dźwigary szkieletu słup przejmuje cały ciężar konstrukcji pozostawiając ściany wolne od obciążenia,

2. niezależność szkieletu i ścian zewnętrznych i wewnętrznych - oferuje nam to słup nośny,

3. „plan otwarty” szkielet - środek wyrazu technicznego - staje się wyrazem estetycznym, tak aby wewnętrzna przestrzeń domu kształtowała się w różnorodny i ciekawy sposób, pozwala to na otwieranie dużych połaci domu i powoduje wzajemne przenikanie przestrzeni wewnętrznej i zewnętrznej,

4. swobodna elewacja jest możliwa przy konstrukcji szkieletowej,

5. ogród na dachu nadając otwartości domu i dodatkowej przestrzeni dla domu.

Willa Savoie spetnia powyższe zasady. Dom stanowi bryła otwarta z każdej strony i wzniesiona na słupach, tak że przez cały dzień jasność zalewa całe wnętrza nie tylko przestrzeń przy murach z określonej strony. Otwartość formy powoduje że willa nie ma strony frontowej.

Pokój mieszkalny ma okna przesuwane poziomo po obu bokach. Trzecia ściana jest zupetnie przeszklona, połowa tej przegrody daje się łatwo przesuwać. Pokój daje się łatwo przystosowywać do aktualnej funkcji, dając kontakt zarówno z wnętrzem domu jak i zewnętrzem.

Pochylnia pozwala na niemal nieświadome przejście z jednego poziomu na drugi, dzieli się na część będącq we wnętrzu domu i cześć prowadzona po ścianie zewnętrznej do ogrodu na dachu. Oprócz pochylni, sa jeszcze spiralne schody realizujące zasadę otwartego planu [9].

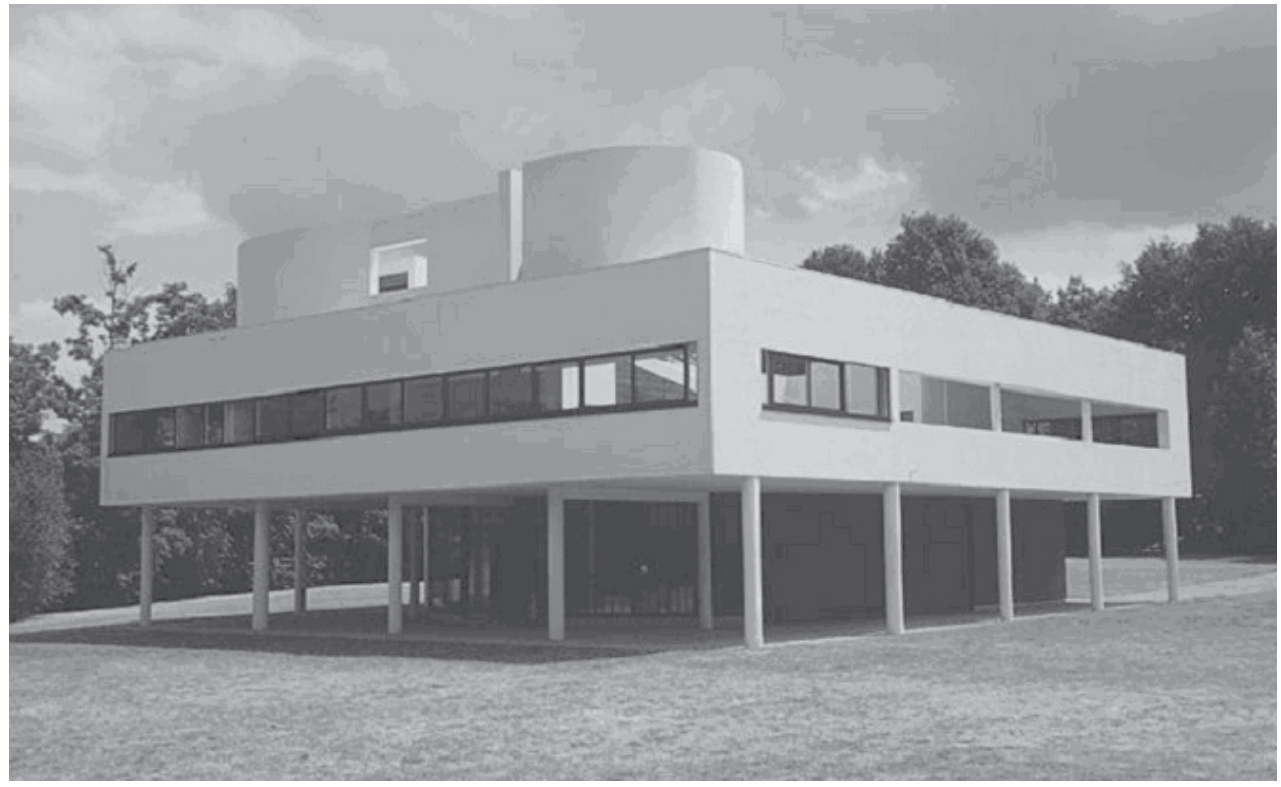




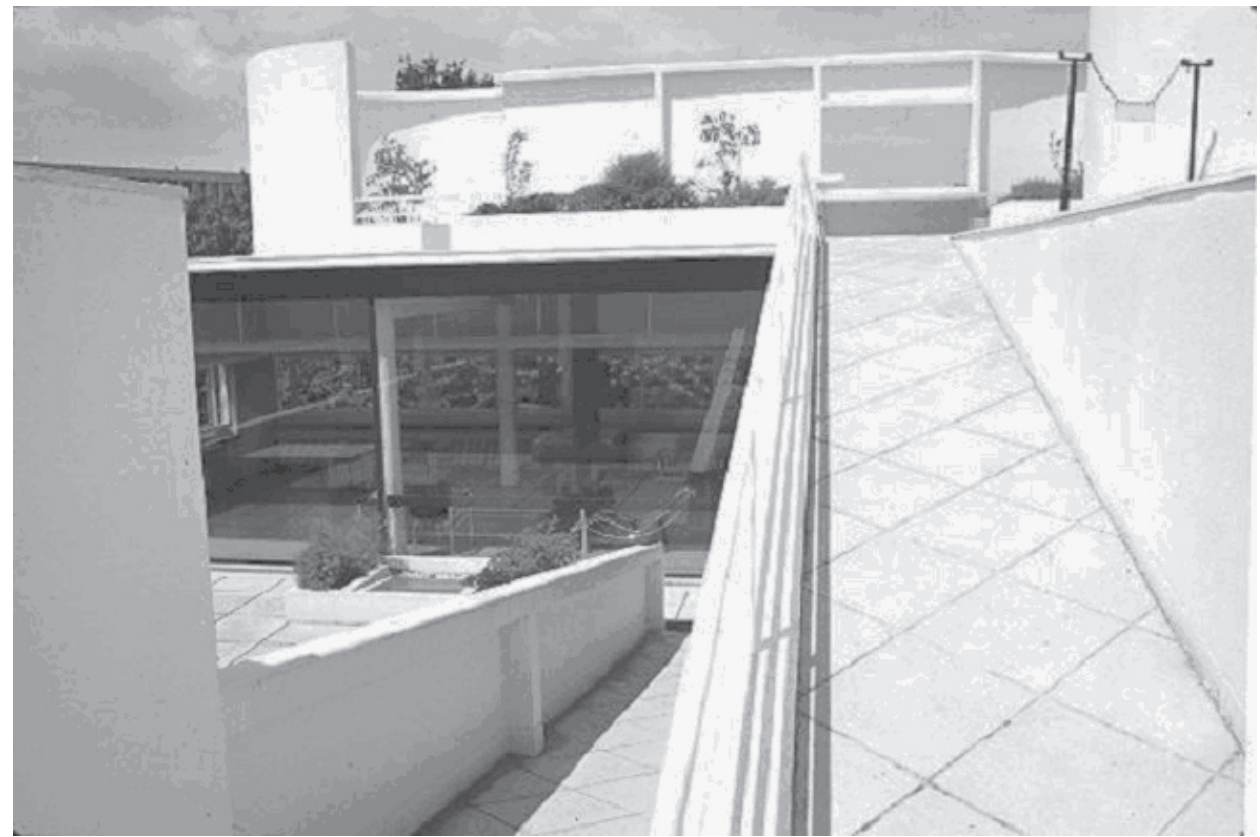

Rys. 6. Villa Savoy w Poissy, 1928-31 Francja. www.bc.edu.

Fig. 6. Villa Savoy in Poissy, 1928-31 France.

Innym architektem propagującym nowe idee jest Ludwig Mies van der Rohe, Zrealizowane przez niego szklane domy stały się wkrótce archetypami. Wczesnym przykładem jest pawilon wystawowy wzniesiony w w Barcelonie w 1929 roku, jako parterowy budynek o ogromnych przeszkleniach, o świetnie ukształtowanym wnętrzu, w którym wyróżniała się jedność przestrzeni płaszczyzn i konstrukcji właśnie za pomocą tafli szkła i pokrytego marmurem, żelbetu.

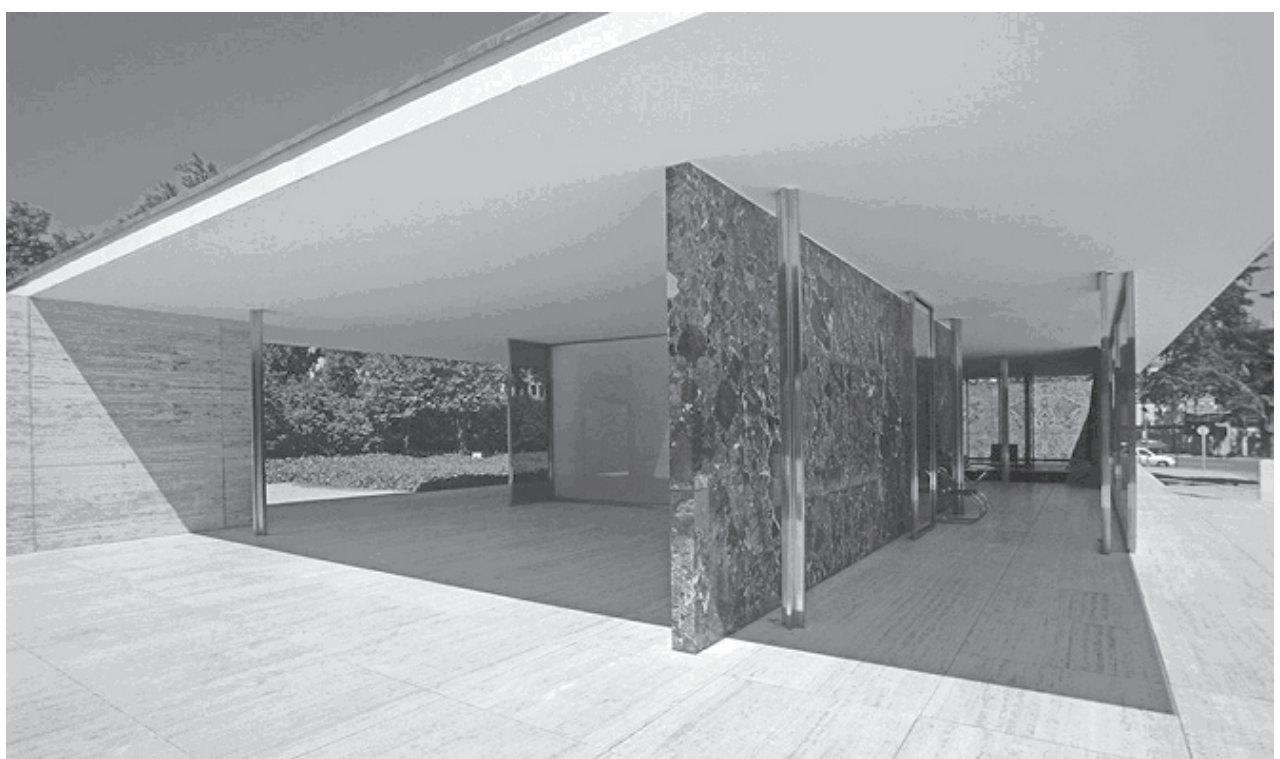




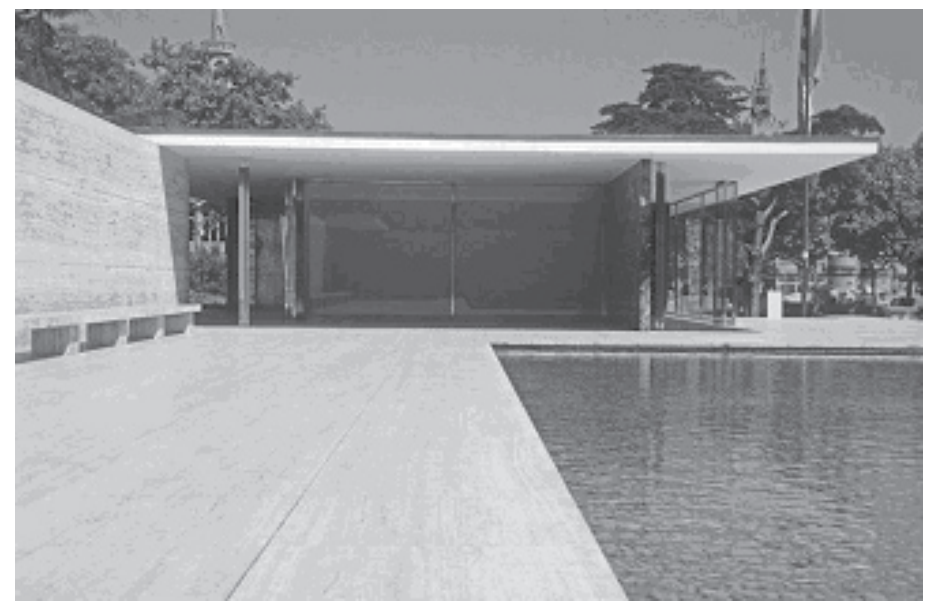

Rys. 7. Pawilon wystawowy w Barcelonie 1986 (rekonstrukcja), Niemcy. Zdjęcie/Photo: Hans Peter Schaefer, www.wikipedia.pl.

Fig. 7. Exhibition pavilion In Barcelona 1986 (reconstruction), Germany.

Później repliki „szklanych gigantów” mniej lub bardziej udane możemy obejrzeć w wielu krajach. Czasami wykonywane w prymitywnych warunkach, przy poświęceniu zwykłych robotników, ale dające satysfakcję i zbliżenie do wielkiej sztuki. Poprzestając jednak na estetycznych aspektach zagadnienia, warto zauważyć że w miarę ogólnej ewolucji modernizmu, odwrót od ściany osłonowej ku rozwiązaniom bardziej dynamicznym i zróżnicowanym regionalnie w latach sześćdziesiątych, kiedy coraz częściej przywraca się oknu jego prawdziwa rolę, a ścianie jej wartości termiczne i dekoracyjne.

Przykładem stał się wielokrotnie publikowany dom własny architekta Kisho Kurokawy w Karuizawa, składający się z kapsuł pokrytych rdzewiejącą powierzchniowo stalą. Takie zestawienie jest charakterystyczne dla architektury japońskiej tego czasu, poszukującej własnej drogi syntezy importowanego zachodniego modernizmu i własnej tradycji.

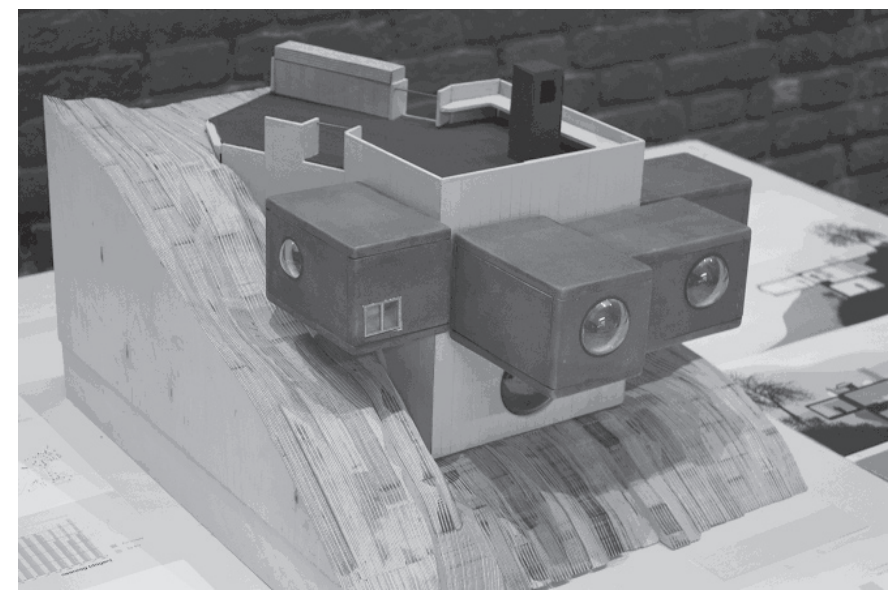

Rys. 8. Kurokawa's holiday time capsule w Karuizawa, 1974 -79 Japonia.

Zdjęcie/Photo: Peter Smisek. http://petersmisek.wordpress.com

Fig. 8. Kurokawa's holiday time capsule in Karuizawa, 1974 -79 Japan. 
Po wydaniu olbrzymiej ilości patentów dla „nowej technologii” nastąpiło zafascynowanie możliwościami jakie daje ówczesna technika. Usprawnienia budowlane, szybko montowane struktury przestrzenne, detale, instalacje. Stworzyło to podstawy do działalności Archigramu, a w konsekwencji do utożsamienia wartości estetycznej budynku z jego sprawnością techniczną. Dla krajów bardziej zacofanych stało się to nowym argumentem za ideologią szklanych domów nad czym trzeba jeszcze pracować, by dorównać innym krajom, natomiast w bogatych krajach coraz rzadziej architekci zajmują się tym tematem.

\section{Jak szklane idee $z$ lat 30-tych wpłynęły na to co mamy dziś i jak to może wpłynąć na przyszłość? Czyli o skutkach idei szklanych domów}

Tak wyglądała sytuacja z ideą przezroczystości w architekturze. Chciałabym zająć się współczesnymi - najnowszymi realizacjami idei szklanych domów, gdyż interesują mnie skutki jakie wywarły owe idee z lat 30-tych na to co dziś możemy dostrzec. Dlatego przyjrzyjmy się projektom z ostatniego konkursu „Dom Przyszłości”.

Dzisiaj dzięki wielu możliwościom zastosowania szkła, pomieszczenia mogą stać się optycznie większe, jaśniejsze ale także podzielone bez utraty przestrzeni. Zastosowanie szklanych elementów we wnętrzach nada im dużej lekkości, a ich nowoczesne wzornictwo, które dostosowujemy indywidualnie do każdego wnętrza. Ponieważ, że szkło jest materiałem ciągle doskonalonym o zastosowaniach niemal nieograniczonych.

Są to fasady podwójne, o powierzchni refleksyjnej lub nie, z grą kolorów zharmonizowanych lub kontrastujących, z nadrukiem wzorów geometrycznych lub obrazowych są konkretnymi rozwiązaniami odpowiadającymi wymogom estetycznym i technicznym wysokiej jakości.

Mamy do dyspozycji różnego rodzaju szkła barwione i szkła z powłoką kolorową, szkła ornamentowe, szkła grube i szkła refleksyjne, czy fasady szklone strukturalnie, które zostały udoskonalone na przestrzeni czasu przez producentów dla potrzeb rozwijających się tendencji architektury, a przede wszystkim potrzeb człowieka. Mimo, że preferowane są zdecydowanie szkła o neutralnym wyglądzie i niskiej refleksyjności.

Grimshaw przewiduje, że „w przyszłości nie będziemy projektować budynków, ale organizmy zdolne do zmian i adaptacji w stopniu zgodnym z technologią chwili, w której się znajdujemy". Uważam, że twarda struktura organizmu musi istnieć, by zapewnić mu podstawową użyteczność. Dom powinien zachować pewne cechy stałości i bezpieczeństwa. Natomiast powinien się zmieniać zgodnie z życiem mieszkającej w nim rodziny. Żyć z mieszkańcami i zmieniać się - przystosowywać się do zmian jakie mogą zajść wśród owej rodziny.

Tak jak domy le Corbusiera, które „podejmowały problem czy próbę otwarcia domu, dania nowych możliwości połączenia wnętrza i elewacji zewnętrznej. Człowiek potrzebuje pomieszczeń, które mogłyby być otwierane i zamykane zgodnie z życzeniem, pokojów których ściany mogłyby opaść na żądanie. Kiedyś uzyskanie tego typu mieszkań było poza zasięgiem koncepcyjnym jak i wykonania. Konstruk- 
cja szkieletowa miała związek z naszymi na wpół zrealizowanymi pragnieniami, starając się je przewidzieć. Dziś w połączeniu z nowoczesną technologią jest to możliwe do zrealizowania".

Domy muszą być funkcjonalne, inteligentne i piękne. To miejsce gdzie możemy odpocząć, być w poczuciu intymności i bezpieczeństwa. Przezroczyste ściany rozwiązują kolejny problem człowieka, który opuszcza swoje miejsce pracy i szuka kontaktu z naturą, ze wsią czy z niebem. Próby odnowienia naszych związków z przyrodą są zawsze bez względu gdzie i jak mieszkamy. Człowiek chce cieszyć się widokiem, czuć podmuch wiatru i mieć dużo słońca. Chce żyć tą naturalną swobodą jakiej mu brakowało w zamkniętym murami domu. Dlatego uważam, że dom powinien być związany jak roślina z miejscem gdzie się znajduje, powinien być jego integralną częścią - częścią całości.

W konkursach na dom przyszłości jaki zorganizowało wydawnictwo Murator i fundacja Dom dostępny, wskazywano na nowe technologie: „,zasilanie energiami „ekologicznymi”, konstrukcje ze stali i szkła i tworzyw sztucznych, komputery. Można było spotkać też domy tradycyjne - murowane, z drewna lub żelbetu. Często były to projekty „współczesne”, a niektóre odgrzewały stare koncepcje. Jednak przewyższały wizje Domu Przyszłości jako organizmu żywego, który zmienia się wedle zmian sposobu użytkowania, ale i w rytmie doby, roku i pokolenia. Słońce, wiatr deszcz, wegetacja i szereg innych czynników dynamicznych zmieniają tradycyjną bryłę. Dom nie ma zwykłych okien i drzwi, nie ma dachu. Pojawiają się siatki słupów podpierających płyty, belki, wsporniki, kratki, cięgna i siłowniki.”[5]

Myślę, że sama bryła nie jest tutaj tak istotna. Ważne jest aby dom był otwarty na świat, aby człowiek nie czuł się w nim jak w zamkniętej klatce, aby mógł mieć kontakt z przyrodą i naturą - źródłem życia. Tak aby również był stałym gruntem i trwałym schronieniem rodziny. Natomiast jeśli owa rodzina potrzebuje czuć się bezpiecznie jak w twierdzy, to na pewno twierdzę powinny tworzyć ogrodzenie działki, a nie ściany domu, gdyż będą przytłaczać i ograniczać mieszkańców, np. w takiej sytuacji proponowałabym rozwiązania domu Dum Eggo z Pragi. Gdzie możliwe są do zrealizowania potrzeby człowieka o których wspomniałam powyżej, natomiast dla osób z zewnątrz będąc twierdzą.

Świat jest od nas oddzielony, ale my możemy go zawsze obserwować. Szklany prostopadłościan z podwojonego szkła daje takie możliwości. Jest domem zamkniętym szczelnie, choć pozornie otwartym. Skóra, opoka otaczająca wnętrze może zależnie od potrzeb łączyć i dzielić. Otwierać i zamykać. Być przejrzysta, a niekiedy matowa. To rozwiązanie nie tylko wykracza daleko w przyszłość, ale szanuje przeszłość i to, co człowiek z nią przynosi, łączy go z naturą. Mamy tu inne postrzeganie przestrzeni bardziej łączące z naturą, gdzie dom jest organizmem na ziemi, posiadający układ kości i oddychającą skórę.

\section{Literatura}

[1] Wujek J., Mity i utopie architektury XX wieku, Arkady, Warszawa 1986.

[2] Basista A., Kompozycja dzieła architektury, Uniwersitas, Kraków 2006.

[3] Broniewski T., Historia architektury - ostatnie dwa stulecia, zakład narodowy im. Ossolińskich, Warszawa 1967.

[4] Pile J., Historia Wnętrz, Arkady, Warszawa 2000. 
[5] Dom przyszłości, Murator, Warszawa 2005.

[6] Rewers E., Przestrzeń, filozofia i architektura, Fundacja Humaniora, Poznań 1999.

[7] Żeromski S., Przedwiośnie, Państwowy Instytut Wydawniczy, Warszawa 1995.

[8] http://staropolska.gimnazjum.com.pl/tradycja/sredniowiecze/Otto_von_Simson_01. html\#forma na podst. wyd. O. von Simson, Katedra gotycka - jej narodziny i znaczenie, tłum. A. Paliñska, Warszawa 1989.

\section{Glass houses}

\section{Katarzyna Szmuryło}

Lublin University of Technology, Faculty of Civil Engineering and Architecture, Chair of Architecture Urban Design and Spatial Planning, Nadbystrzycka 40, 20-618 Lublin, e-mail: katarzynaszmurylo@gmail.com

Abstract: It's about, how glass houses look like today, if they are neglected remnants of past times. Has this idea survived to our times, maybe launched something new or evolved? Is a transparency of residential architecture needed in a such extent? It's also about opportunities, that are given to us by glass, which is still a material bringing to perfection with almost unlimited applications for the purpose of developing trends of architecture, and above all human needs. Grimshaw provides that "in future, we will not design buildings, but organisms able to change and adapt to the extent compatible with the technology of the time, in which we find ourselves". Houses must be functional, intelligent and beautiful. This is a place where we can relax, have a sense of privacy and security. Attempts to renew our relationship with nature are always regardless of where and how we live. Man wants to enjoy the view, feels flurry of wind and have lots of sun.

Key words: Housing architecture, glass houses idea, framework construction, curtain wall. 